\title{
Conceptualizing Feminist Strategies for Russian Reproductive Politics: Abortion, Surrogate Motherhood, and Family Support after Socialism
}

$\mathrm{T}$

he question of whether and how feminist concepts and paradigms developed in Western, liberal contexts may be relevant for struggles for gender equality in former socialist states has been a central point of debate between and among feminists West and East since the late 1980s. ${ }^{1}$ In one of the most thought-provoking and important statements on this issue, Nanette Funk (2004) cautioned that US feminist critiques of AngloAmerican liberalism cannot be readily exported to make sense of liberal campaigns in Central and Eastern Europe and the former Soviet Union. Funk characterizes this critique of Anglo-American liberalism as having five key dimensions: first, that liberalism endows rights and goods to individuals, rather than recognizing nonindividual goods and rights, and fails to recognize that individuals may perceive themselves as having duties to broader collectives; second, that liberalism endorses a neutral vision of the state rather than recognizing that the state inevitably conveys political goals and visions; third, that liberalism's value of independence does not adequately recognize human dependency; fourth, that liberalism imagines persons as disembodied, neglecting the ways bodies are gendered, raced, classed; and finally, that liberalism's distinction between public and private spheres obscures the gendered power of men in both public and private, and fails to acknowledge how women's subordination is ensured by their relegation to the private sphere $(2004$, 704).

Funk then proceeds to survey the historically expansive philosophical landscape of liberal thought throughout Eastern Europe and Russia, demonstrating how this complex body of social and political theory has sub-

I express heartfelt thanks to Maxine Eichner, Beth Holmgren, Julie Hemment, Janet Johnson, Nadia Kizenko, Andrea Mazzarino, Ziggy Rivkin-Fish, and Tatiana Zhurzhenko for their helpful feedback on earlier drafts. Special appreciation goes to Nadia Kizenko, Elena Gapova, and Kari Points for providing invaluable insights and resources. I am deeply indebted to Nanette Funk for her inspiration and support throughout my career. All remaining errors are mine.

${ }^{1}$ See Funk and Mueller (1993), Holmgren (1995), Snitow (1999), Gal and Kligman (2000), Rivkin-Fish (2005), Hemment (2007), Johnson and Robinson (2007), Cerwonka (2008), and Borovoy and Ghodsee (2012).

[Signs: Journal of Women in Culture and Society 2013, vol. 38, no. 3]

(C) 2013 by The University of Chicago. All rights reserved. 0097-9740/2013/3803-0004\$10.00 
stantially differed from American formations of liberalism. The region's liberals, for example, have always recognized collective goods and rights; they have endorsed a conception of the state as having a religious and moral mission, not remaining neutral in relation to citizens' own understandings of the good life. They have not assumed a disembodied autonomous actor but have promoted the need for sacrifice and duty-especially gendered forms of duty to the family and nation-as taking precedence over individual rights. Moreover, Eastern and Central European liberals have placed extensive emphasis on dependency, particularly of individuals on the state, and made little effort to cultivate individual independence in either an economic or political sense; there has been minimal attention to the need for a private sphere protected from state influence. Central to these ideas, Funk explains, is that the region's multiple liberalisms have endorsed relational forms of personhood, which she problematizes as giving rise to norms of gendered duties and sacrifice for the collective good-and resulting in women's subordination.

Given these historically specific forms of liberalism, she cautions, contemporary feminist critiques of American liberalism will likely miss the mark in capturing the particular forms of gendered domination in Eastern and Central Europe. Indeed, Funk posits that feminist critiques of American society's prized notions of autonomous individualism and the insulated private sphere are not appropriate paradigms on which to base struggles for gender equality in that region, because these specific components of liberalism have not been widely embraced there. Nor can critiques of neoliberalism effectively be phrased in terms of "revaluing dependency" (Funk 2004,708 ), an approach central to the feminist defense of social welfare programs in the United States. ${ }^{2}$ Funk argues that feminists should support contemporary local struggles that endorse individual rights and a renewed private sphere, and that eschew citizens' dependency on the state, as a means of recognizing the specific histories and contemporary problematics against which local progressives and feminists are struggling.

This article takes up the challenges Funk poses to explore the possible contours of feminist intervention in the realm of Russian reproductive politics - specifically, abortion access, surrogate motherhood, and family support. Inspired and challenged by Funk's concerns, I examine whether and how endorsing women's autonomy and a private sphere may be important for promoting Russian women's interests in reproductive politics; I

\footnotetext{
${ }^{2}$ It is important to note that US feminists, too, are careful to distinguish between "dependence that is rooted in unjust... social institutions" and "socially necessary dependency," such as that inherent in the human life course (Fraser and Gordon 1994, 24).
} 
also attend to these concepts' potential to expand the legitimacy of feminist perspectives among Russian stakeholders. Additionally, I address the complex issue of conceptualizing a feminist politics of social welfare in this formerly socialist, neoliberal, and nationalist policy context. In analyzing each reproductive issue, I examine its historical and legal configurations and offer a feminist analysis of the ways these configurations contribute to gendered inequities. Further, I highlight the local symbolic formations and political interests that shape the ways each issue has (or has not) been construed as a gendered problem of broader public concern in Russian society. Strategizing about how to address the gaps between feminist political perspectives and local knowledge formations is a major concern among feminist anthropologists (Hemment 2007; Borovoy and Ghodsee 2012). In reflecting on feminist strategies for Russian reproductive politics that may bridge those divides, I attend to the potential concerns that feminists may have while maintaining a pragmatic stance about the need for culturally informed engagement to promote gender equality.

Methodologically, this article draws on a range of sources and data that vary for each of the three issues I examine. My overarching argument about the challenges of conceptualizing feminist strategies in Russia builds on nineteen years of anthropological engagement with Russia's reproductive politics, including fifteen months of participant-observation fieldwork and long-term key informant relationships that extend from 1994 to the present through visits, phone and Skype calls, and e-mail correspondence. My analysis of the policy dimensions, social movements, and broader discursive formations of abortion and family support are based on extensive analysis of Russian-language media, demographic analyses of fertility trends and politics, and sociological texts on the family, from the late 1960s through the present. Unlike those issues, which have a long history of politicization, surrogacy is a post-Soviet phenomenon that is just beginning to be publicly debated. My analysis offers a preliminary mapping of the emerging terrain of Russian surrogacy politics, drawing on four sources: Russia's surrogacy legislation, a website in which would-be surrogates advertise themselves and women seeking to hire surrogates post narratives of their experiences, a Russian Orthodox Church website with critiques and debates on surrogacy, and secondary literature analyzing Russia's surrogacy policies. The online discussion board provides a unique, if preliminary glimpse into the ways legal and commercial structures set women against each other in a microlevel conflict of interests; although I cannot establish whether the postings I analyze are representative of Russian surrogate relationships in general, my analysis reveals what is culturally pos- 
sible for women to assert as they construct their interests as both surrogates and commissioning mothers. The politics of surrogacy at both microand macrolevels reveal conceptual challenges for feminist strategizing that are quite distinct from those at stake in abortion and family support politics, where the state is a dominant regulatory presence. In the neoliberal, marketized context of surrogacy, women's inequality is structured on the basis of both infertility and poverty, through competition with other women, and the church, rather than the state, is asserting its political voice for reform.

The article illuminates three pressing questions: First, how might notions of individual autonomy and a private sphere enable a reshaping of the particular kinds of subordination that have emerged historically and that presently configure Russian women's status on particular reproductive issues? Second, to what extent would notions of individual autonomy and a private sphere be culturally salient, able to resonate locally with existing values and thereby feasible for mobilizing progressive change on reproductive issues? Third, if a revaluation of the concept of dependency is not a viable feminist strategy in a context where decades of centralized state power produced a crippling socioeconomic, gendered dependency, how do we conceptualize a feminist politics of social welfare? The article argues that a feminist stance must maintain critical attention to the historical forms of domination produced by both the centralized state/economy during socialism and the neoliberal state/economy of the past two decades. Such formations may selectively draw on liberal feminist ideals such as individual autonomy and privacy while combining them with attention to the value of care work as a matter of justice (Tronto 1993; Fraser and Gordon 1994; Eichner 2010). Much work remains to be done in articulating, clarifying, and achieving these hybrid visions.

\section{The politics of abortion and contraception}

In 1920, the Soviet Union became the first country in the world to legalize abortion. Policy makers considered abortion access necessary for emancipating women from the home and mobilizing them into the labor force. Yet they did not condone the limitation of births, and neither promoted contraceptives nor ensured their availability. In 1936 Josef Stalin recriminalized abortion as part of his drive to increase the birthrate; this resulted in grim surges of maternal mortality as women sought illegal and unsafe abortions en masse. In 1955, Nikita Khrushchev legalized the procedure in order to prevent these deaths. Yet Soviet leaders and physicians denounced abortion as both dangerous and immoral, an antisocial act re- 
presenting women's rejection of motherhood (Field 2007). This rhetoric existed despite the fact that the Soviet government made very little effort to produce or import contraceptives and did not endorse the prevention of unwanted pregnancy. In fact, the state was actively pronatalist and urged women to give birth. Considering abortion an undesirable social practice, state officials gave no thought to women's comfort during the procedure. In many cases, women endured abortions in large wards without privacy, in clinics they described as factories or meat grinders (miasorubki), and even without anesthesia. Some doctors spoke of women as needing to suffer or feel guilty about abortions as punishment for their refusal of motherhood (Rivkin-Fish 1994).

After the Soviet collapse, many branded abortion a sign of the delegitimized past that should be eliminated. Progressives and conservatives approached this process in dramatically different ways. Progressives founded family planning clinics, working with Western aid agencies and pharmaceutical firms to promote contraceptives instead of abortion as a main means of fertility control. Significantly, Russia's abortion rate has steadily declined from 100 per 1,000 women of reproductive age in 1991, to 55 in 2000, and to 44.1 in 2005 (Sakevich 2007). This occurred despite the fact that in the late 1980s the Ministry of Health expanded the criteria through which women could access abortion in the second trimester to include circumstances related to poverty and social marginalization. In expanding these so-called social criteria for abortion, the state implicitly recognized that women's use of abortion occurred in conditions of dire necessity, including abject poverty, unemployment, sickness, disability, and a husband's death or incarceration.

Conservatives took a very different approach to combatting abortion. From the beginning of the 1990s, Russian nationalists seized on abortion and contraceptives as insidious practices contributing to the nation's low fertility and rapidly decreasing population (Rivkin-Fish 2006). Alarmed at what they termed Russia's demographic catastrophe, they portrayed contraception as a cynical Western ruse to further Russia's population decline by convincing women to refuse childbearing (Mikhalych 1997; Novaia Gazeta 1999). Supporters of this nationalist demographic politics have thus construed abortion and contraception as issues of national security practices linked to the country's weakened geopolitical power. They portray the criminalization of abortion as a means of increasing fertility and strengthening Russia geopolitically, socially, and spiritually. Their unrelenting campaigns and legislative proposals to restrict or criminalize abortion have borne steady results: in 2003 and again in 2007 the Ministry of Health, without soliciting public debate, reduced the criteria through 
which women could access second-trimester abortions (Pravitel'stvo RF 2003, Timashova 2003; Papyrin 2007). This shift is curious, given that second-trimester abortions are continually declining and now constitute a tiny proportion of all abortions. In 2000, 43,687 second-trimester "social abortions" were recorded in Ministry of Health clinics; these comprised 2.57 percent of the total number of abortions undertaken in these clinics. By 2010 , this number had declined to 392 , or 0.05 percent of all abortions in these clinics (Sakevich 2012).

In June 2011, Parliamentarian V. G. Draganov introduced draft legislation requiring women to get written permission from their husbands, and minors to get written permission from a parent or guardian, to obtain abortions; a waiting period of seven days to receive an abortion (except in the eleventh week of gestation, in which case the waiting period would be reduced to forty-eight hours); a mandatory ultrasound in which a woman was to see and hear the fetus's beating heart; and a counseling session informing women about the harms of abortion and her "right to refuse" an abortion (the ultrasound and counseling were described as part of the informed consent process). The bill also proposed eliminating all social criteria for second-trimester abortion except when a pregnancy resulted from rape (Draganov 2011). At the time of this writing, these requirements have not all passed; in February 2012, the Russian Ministry of Health agreed to restrict second-trimester abortion except in cases where the pregnancy resulted from rape (Putin 2012). Yet with ongoing support from the Orthodox Church and global antiabortion movements, further restrictions may emerge, making the question of effective feminist strategies for ensuring abortion access urgent.

\section{Conceptualizing feminist strategies}

Draganov's bill generated the most vibrant public debate yet on abortion politics, arousing the opposition of liberal commentators and even some street protests. Bloggers initiated an online petition opposing it. Interestingly, one of the main ways these advocates defended abortion access was by asserting the need to "fight abortion, not women." In one of the very first public demonstrations ever, protestors held signs reading, "We are against abortion" and "A child must be wanted"-implicit references to the legitimacy of contraceptives. ${ }^{3}$ St Petersburg sociologist Olga Brednikova cogently argued for reframing the issue from one of solving the "problem of abortion" to one of asking, "how to ease the burden of

\footnotetext{
${ }^{3}$ See http://gaidarfund.ru/projects.php?chapter=project_club_discuss\&id=60.
} 
abortion for women," a paradigm that involves recognizing women as subjects. ${ }^{4}$

Brednikova's call to reintroduce women's voices to the debate suggests that Funk's calls for feminist struggles oriented toward women's rights and individual autonomy, and against calls for sacrifice in the name of the nation, seem readily applicable to Russia's abortion politics. Funk's argument that gender equality would be enhanced by developing "a feminist conception of the public/private distinction" $(2004,713)$ to protect women from an intrusive state also makes sense. Such developments may be in the incipient stages. When, in April 2011, abortion opponents drafted a bill to end public financing of abortion, several women Duma members rejected it on the basis that "women have the right to decide independently about their own fate" (Regions.ru 2011). It is notable that neither the deputies nor any other proponents of legally accessible, publicly funded abortion have deployed the concept of choice, inasmuch as Russian women have widely experienced abortion as a symptom of their lack of choices, both to prevent pregnancy and to raise their desired number of children. Moreover, women Duma members and social activists who opposed the bill highlighted how extensive poverty impedes women from deciding to bear more children, rather than emphasizing the principle of individual autonomy. Several emphasized the likelihood that unsafe abortions, rather than a higher fertility rate, would result from financial or legal restrictions on the procedure.

Rhetorical references to poverty as a cause for protecting abortion access should raise feminist concerns: the failure to recognize women's right to autonomy leaves open the possibility that methods such as means-testing could determine a woman's abortion access, or that social welfare provisions could be offered to pregnant women, fetuses, and babies in lieu of abortion rights. Certainly, the idea that women have the right to autonomous decisions about their bodies exists in Russia, and this implies the necessity of a private sphere outside of state control. Yet the predominant focus on socioeconomic constraints to childbearing may also reflect a cultural skepticism about the practical significance of legal rights in contemporary Russia (Turbine 2007), where juridical protections have been notoriously weak. This ambivalence about rights as meaningful personal protections also cuts the other way, as some feminist commentators have evaluated the significance of proposed restrictions on abortion from the perspective of women's practical possibilities for subverting the law rather than as a matter

\footnotetext{
${ }^{4}$ This quotation appeared on the Gaidar Fund's website in 2011 but has since been removed.
} 
of principle. ${ }^{5}$ Russian gender sociologist, Anna Temkina, for example, remarked, "It would seem that the [proposed] law should generate great protest, because it's unlikely that Russian women will give up their longstanding rights. My cautious hypothesis is that people are not as much interested in the law, as in the ways they will be able to find to get around the barriers. . . . Long experiences of daily practice reveal that people are able to adapt, and go around the law. In general, the middle class will suffer less, inasmuch as they undergo far fewer abortions and when they do, they get them in private clinics" (Roundtable 2011, 11).

Even if feminists did pursue legal guarantees for abortion rights, liberal notions of individual autonomy and a private sphere may not be judged sufficient moral foundations for preserving these rights in the face of increasingly prevalent arguments by church authorities that abortion constitutes the "murder" of a "child." Ubiquitous anxieties over Russia's demographic crisis further constrain the rhetorical possibilities for feminist interventions. For example, soon after reproductive health advocates established the Russian Family Planning Association in 1993, the Orthodox Church and others concerned with reversing low and declining fertility lobbied the Duma vigorously against supporting family planning. Politicians rescinded state funding for contraceptives as a matter of promoting national interests in increasing the birthrate (Babasyan 1999). The state's continued willingness to imprint its demographic interests onto women's bodies suggests that promoting the value of a private sphere is both important and fraught with dangers for feminists. Feminist arguments that women have the right to make autonomous decisions about their reproductive lives need to be carefully constructed to avoid being taken as evidence that feminism is hostile to children and inimical to the nation's demographic vitality. For while it is mainly extreme nationalists and Orthodox Church adherents who reject contraceptives, the notion that contraceptive use in and of itself lowers the birthrate is very widespread (Ekho Moskvy 2010). Feminists would do well to explain that women have been controlling their fertility in Russia for decades but have had limited means for doing so safely. It is imperative to reframe contraceptives as enhancing women's health and fertility by reducing both the abortion rate and cases of secondary sterility that result from poor quality or underground abortions. For poststructuralist critics, this kind of rhetoric may appear problematically complicit with essentialist views of women as naturally desiring to bear children. Yet promoting

\footnotetext{
${ }^{5}$ Although some protests against abortion restrictions have recently occurred, it does not seem that feminists are conceptualizing a mass strategy of collective action to ensure legal abortion rights.
} 
contraceptives as a legitimate tool for promoting healthy childbearing will serve to legitimize feminism as a social force for positive change. Incipient Russian framings of contraceptive services as societal investments in the protection of women's health, the prevention of abortion, and the promotion of timely pregnancies are the most promising way to promote women's reproductive autonomy in this hostile, nationalist context.

\section{Surrogate motherhood: Commercializing women's interrelations}

If the state's demographic concerns align with the Orthodox Church's goal to restrict abortion, these institutions differ in their position on surrogate motherhood. Presently, Russia's juridical treatment of surrogate motherhood creates broad opportunities for the practice, explicitly permitting commercial surrogacy. Order 67 of the Ministry for Health specifies that married couples or single women may use a surrogate when the commissioning woman is biologically unable to conceive or carry a pregnancy to term. Surrogate mothers must have at least one healthy child of their own, demonstrate that they are mentally and physically healthy, and be between twenty and thirty-five years old. They can be married or single and may or may not donate their own gametes. ${ }^{6}$ The surrogate can receive compensation for her services and expenses connected with the pregnancy and birth. However, the law does not establish guidelines for how such fees should be determined and states that a written contract specifying the terms of the agreement is not mandatory. Interestingly, it recognizes contracts that are created only with regard to enforcing the commissioning parties' financial responsibilities to the surrogate, not for determining custody of the child in the case of disputes. Surrogate mothers maintain all rights to the child regardless of the terms of a written contract (Points 2009; Svitnev n.d.).

The legislation's ethical concerns include ensuring the voluntary character of participation through written informed consent; recognizing and privileging the gestational surrogate's infant bond, even without a genetic relationship; and preventing surrogates' exploitation by allowing payment, providing no restrictions on the amount of payment, and viewing any financial contracts that establish commissioning parties' financial responsibility to surrogates as binding. Analyzing comparative legislation on surrogacy, Kari Points (2009) observes that Russia stands out in its minimal scope of regulations and lack of sanctions for the transgression of existing requirements (35). Nor have Russian officials welcomed public debate in

\footnotetext{
${ }^{6}$ Further, the legislation requires written informed consent from all parties.
} 
establishing this legislation, in contrast with Great Britain and Canada, where women's groups, bioethicists, politicians, and industry leaders have pressed their interests (34).

Opposing the state and surrogate advocates, in 2011 Russia's Orthodox Church began avidly condemning surrogate motherhood as a new form of prostitution. Prompted by its increasing commonality in society (including the case of a high-profile rock celebrity, Fillip Kirkorov, who hired an American surrogate to bear him a child), Archpriest Dimitrii Smirnov insisted that surrogacy dehumanizes people, treating them as "machines" (Smirnov 2011 ) or "farms" for growing people; he highlighted how surrogacy enables the rich to exploit the poor (Smirnov 2012). Deacon Andrej Kuraev affirmed the ethical impermissibility of "alienating people from their bodies" (Poedinik 2012). These analogies reflect Russia's cultural framing of surrogacy as an economic exchange, which sharply differs from US framings as a "gift of life," compensated by financial "gifts" rather than payments or fees (Ragoné 1994, 32). Largely bypassing the issue of surrogates' exploitation, supporters of surrogacy have claimed that "everyone has the right to be a parent" (Poedinik 2012).

The complex political dynamics at stake for women on both sides of the surrogacy relationship are evident in their Web postings on Surrogacy.ru. ${ }^{7}$ In the following section, I examine postings by commissioning women, who articulate a deep sense of vulnerability in an unregulated commercial surrogacy market. I then explore two postings by women offering their services as surrogates, analyzing how they position their interests and aim to protect themselves from exploitation. While it is difficult to say whether the examples on this website are representative of most Russian surrogacy negotiations, they do provide insights into the discursive framings through which women - as both commissioning mothers and surrogates-find it possible to express their interests and attempt to manage competition with others. In examining these discourses and the political contours of surrogacy in this unregulated context, I aim to illuminate the multiple forms of gender inequity at stake and explore whether liberal concerns for autonomy and a private sphere may be valuable, or how they may be limited, for devising feminist strategies.

A central topic commissioning women address is reflected in the online heading "How to Identify a Fraud? Your Experiences." These narratives provide details of long-suffering infertile women being swindled by manipulative women seeking personal gain. One posting reads:

\footnotetext{
7 These postings were available publicly on the website in January and February 2010. Since the authors posted on an unrestricted site, I have treated them as available for analysis. Since then, however, access to the chat room became restricted to those who register.
} 
Circumstances have left me at 27 years old unable to have children. My husband hasn't left me (and for that, an enormous thank you to him). We decided to use the services of a surrogate mother and ran into a host of problems beyond nightmares. They cheat, come to you already pregnant, etc. They all have unimaginable fees: a one room apartment in Petersburg, \$40-60,000. The surrogate mothers' logic is understandable - “I'm giving birth to a baby for you, giving it to you, so put me in luxury." We can't afford this kind of sum. For that reason I'm addressing the applicants: DON'T CREATE ARTIFICIAL DEMAND. Two years ago the services costs $\$ 5,000$. Have prices risen in these two years 10-15 times? Please share your experiences so we can figure out this problem.

From a feminist perspective concerned with preventing the exploitation of poor women, claims that "artificial demand" has unfairly raised the going rates for surrogates inspire little sympathy. Yet it bears noting that feminists in states that treat the remuneration of surrogacy with caution as a potential ethical violation of human rights and baby selling (e.g., Canada) have maintained the need to clarify the concept of reasonable expenses (Points 2009, 24, 26). The following posting provides further evidence demonstrating that in an unregulated market without authoritative guidelines for the ethical treatment of surrogates, commissioning couples may ignore the question of fair compensation. Yet this narrative also highlights some of the particular vulnerabilities that commissioning women face:

I can conceive a child, but in no way carry it. In the past 15 years of marriage I had 20 hopes, and 20 failures. . . The last hope is a Surrogate Mother. My husband and I began the search. Just as many of you here, we wanted (I wanted) to spend as little money as possible. To find a SM in the Moscow area and in Moscow itself is very expensive. .. . To find a SM here or to send for one from the former Soviet republics and rent her an apartment turns out to be almost the same price. But I tried to save - we had the money, but as anyone managing their household budget, I didn't want to spend more than I had to! But it turned out that I lost Everything! We found a girl from the countryside of a brotherly republic who agreed to our conditions. She came to the capital, we gave her a room in our decent size apartment. The most common, disheveled country girl turned out to be very crafty and capable ... and quickly learned to look decent. Furthermore, she really liked the life of the capital. I can say that women from there are not like our, Russian [women]. [Slur] Ukrainians [khokhlush$k i$ ] as a rule are persistent, smart, and sly. I didn't immediately begin to suspect that something was not okay, at first I was happy that my hus- 
band began coming home from work earlier, each time with a box of chocolates or something else tasty, for the FAMILY dinner. But nature has created us to sense deception immediately. I began to notice a lot of intriguing and unpleasant things. But that's about my suffering! We succeeded in getting pregnant the third time and I kept my SM home with me until 12 weeks under my complete control. Then I found her a little apartment not too far away and rented it. She happily moved out from our place, I breathed a sigh of relief. But happiness didn't return to our home. My husband began to always be delayed at work. And once I caught him with our SM. Very simple, he didn't answer his cell and at work they told me that he left in the very beginning of the morning. I sensed it with my heart . . a and my suspicions were entirely justified. I became hysterical . . but my husband, the closest person to me, told me that I was only half a woman, and he needed a healthy broad, who could bear him healthy children all on her own. That's what happened! I am already 41 years old, I have no husband, I have no child, I have nothing. . . . I can't even adopt a baby because now I am divorced. . . . Don't repeat my mistake, don't bring your SM to live with you.

This commissioning woman's explicit acknowledgment of her effort to save money and maintain strict control over the surrogate reveals how unregulated commercial surrogacy poses threats to surrogate mothers' autonomy. The overt use of an ethnic slur and prejudice against the apparent rural background of the surrogate, who has come to live under the surveillance of the commissioning wife, further reveals the compounding layers of inequality in this relationship, extending from class to ethnicity to regional status. At the same time, this one-sided narrative also enables recognition that surrogates have agency and, in providing a desired service for the commissioning couple, are not merely powerless servants. Nor are commissioning women-despite their economic resources and employer status - situated in a clear-cut dominant position over surrogates. In a cultural context that constructs womanhood through motherhood while stigmatizing adoption, these women's infertility leaves them extraordinarily vulnerable. ${ }^{8}$ It raises the possibility of being defined as less than a real woman, a stigma that women know may lead to abandonment and permanent childlessness.

${ }^{8}$ In 2002, approximately 700,000 children resided in state orphanages (Zabina et al. $2009,162)$. Adoption is often kept secret, shrouded in assumptions that abandoned children are tainted by poor genetics, gestation by HIV-positive or alcoholic mothers, and neglect in state institutions. For the history of Russia's changing cultural ideas about orphans, see Creuziger (1997). 
With current legislation ignoring these multiple dynamics of economic interests and symbolic inequalities, it leaves the two sides to negotiate these relationships themselves, opening the way for conflict and manipulation rather than justice.

Some of the ways these negotiations take place are evident in postings from women offering their services as surrogates. While these advertisements are composed in stylized ways and therefore should not be read as transparent evidence of reality, we can analyze them as performative effects that are revealing in two important ways. First, in attempting to portray themselves in the best possible light, would-be surrogates anticipate the issues of concern to commissioning parents and assert the kinds of terms they are willing to agree to. Second, some of these advertisements undertake rhetorical attempts to justify the payment of "fair" remuneration. The strategies surrogate mothers use to establish an arrangement on terms they find agreeable shed light on the struggles that attend surrogacy arrangements and the informal means through which negotiations take place.

One would-be surrogate addresses commissioning couples' fears by giving extensive details about her health and genetic status. She then emphasizes her sincerity and flexibility in meeting their needs:

I can become a complete SM (the egg is yours + the sperm is yours) or a partial (the egg is mine + sperm is yours).... My husband agrees to this. I live in Saratov oblast' and can temporarily move to your city. I am even tempered, calm, responsible. You don't have to worry, after the birth I will give you the child. My 3 are enough for me. I need to get them taken care of financially... Before taking this step my husband and I discussed it all, more than once. I can assure you that you will not regret it. . . I seek medical care $+9,000$ rubles a month + 350,000 rubles. I will consider your offers. Write to me and tell me what you want. I believe we can reach an agreement and help each other. If it's necessary, then a fictitious marriage is possible. Write me at [e-mail].

This author portrays herself as poised to agree to most any terms at all: to be an egg donor or a gestational surrogate, to move to another city during the pregnancy, to undertake a fictitious marriage. While naming a desired sum, she claims a willingness to entertain other (presumably less lucrative) offers. She portrays her motivation as obtaining the financial wherewithal to care for her existing three children, a goal that she depicts as compatible with all the demands a commissioning couple may have. Although we cannot take this limitless flexibility at face value, it nonetheless raises the troubling specter of how desperation may lead to subservience. Viewed along- 
side the multiple concerns expressed by both surrogates and commissioning women, it is clear that the unregulated commercial surrogacy market has failed to address women's competing interests. The legislative focus on ensuring surrogates' rights to keep the baby should they choose to do so seems to have defined the most pressing issue related to "women's rights" a priori, essentializing women's subjectivity as mothers while ignoring their interests as either workers or as potential victims of discrimination and fraud. Another would-be surrogate, in contrast, clearly asserts her self-interest while taking pains to establish the legitimacy of her financial requirements:

I will help a well-off couple who can give themselves many things, except the happiness of raising their own child. I will not become an egg donor. With regard to payment, I want to immediately dispel the myth about inexpensive surrogate mothers. In order to not offend the feelings of those who have enormous desires and don't have financial resources, I will say that today only well-off people can afford such procedures. For those who still haven't been burned on this problem and who haven't encountered the situation when women agree to one set of conditions of pay, but after conceiving extort them, either for more money or an apartment, don't forget that big problems and headaches may be hidden under sweet responses and low prices. You can't expect a SM will make do with under 20,000 [international units/euros/dollars], it's not worth it for her. . . Today such services will cost a minimum of 2-3 times more. And as one SM on the site rightly noted, everyone knows about the government's project to raise the birthrate in Russia, where the compensation is 250,000 rubles. Is there any reason now to speak of the reward for a $S M$ in the amount of $\$ 10,000$, when any woman who gives birth will not get much less?

And the most important issue is a person simply cannot be cheap! And a person who decides to undertake this act, clearly understanding all the seriousness of the operation and responsibility, and also the consequences for themselves. . . I have a clear understanding of the seriousness of this act and with all responsibility will strive to answer all questions. I will provide all the information you want. I will consider any real offers [e-mail].

This author's tactic of distinguishing herself from surrogates who extort more money than initially agreed upon underscores the existence of a competitive labor market for surrogates. With minimal regulation from the state and an absence of professionals' ethical frameworks, surrogacy involves 
women renting their wombs and purchasing the production of babies as they would any other commodity. Feminist interventions addressing the ethical compromises emerging from women's positioning in surrogacyparticularly vis-à-vis each other-are clearly urgent.

\section{Conceptualizing feminist strategies}

How useful are liberal concepts of individual autonomy and a private sphere for promoting women's interests in Russian surrogacy politics? In Euro-American contexts, feminist proponents of surrogacy argue that the ability to sell one's eggs and contract for pregnancy services enhances women's autonomy in the marketplace, destabilizes the notion that women are "naturally" nurturers (and that nurturing is antithetical to paid labor), and thereby challenges the relegation of women to the private sphere (see Berkhout 2008). Feminist critics, by contrast, raise concerns about the limits of individual autonomy in a situation of severe inequality and women's limited opportunities for economic mobility. They argue that commercial surrogacy objectifies women as tools for others' goals in round-the-clock labor lasting approximately forty weeks, with risks of morbidity and mortality. Moreover, the contracts limit a surrogate's autonomy by prescribing the medicalization of her body and restrictions on her daily activities: the good of producing a healthy "product" requires subordinating the surrogates' own needs and desires, leaving them vulnerable to exploitation and lack of respect (Shanley 2001; Berkhout 2008; Ryan 2009).

As described above, Russia's legal framing of surrogacy represents a neoliberal approach that enables the commodification of women's bodies without regard to the exploitation enabled by market relations. It illustrates the dangers women face in an unregulated private sphere, and the limits of contract theory for ensuring justice and equity for women in Russia. While women's open discussion of their economic interests suggests the basis for transparent discussions about ethical approaches to surrogates' compensation, ensuring a "fair" payment does not preclude the multiple forms of objectification and exploitation that surrogates experience. The perceived need for commissioning parents to undertake surveillance of a surrogate's daily behaviors is something that surrogates themselves presume, as indicated by their willingness to move to commissioning parents' city until after the delivery. This willingness to cease, temporarily, to live with one's own children exposes the degree to which surrogates have internalized the need to become an instrument for the commissioning couple; more research is needed to understand whether surrogates experience autonomy in these relationships, and how. 
Feminist strategies, in Russia as elsewhere, must be sufficiently complex to address the multiple issues at stake in surrogacy (Shanley 2001). Prohibiting the process would drive it underground, making ethical debate and professional guidelines impossible while increasing the likelihood of exploitation. Feminist interventions should address the vulnerabilities incurred by both groups of women in this unregulated market. Advocacy for surrogates should involve arguing for the need to respect women's labor and bodily integrity; recognizing the risks involved in pregnancy, labor, and delivery; and ensuring surrogates' protection from bearing the long-term costs these risks may generate. Advocacy for infertile women should require destigmatizing infertility and childlessness and promoting the cultural acceptability of adoption. By struggling for more ethical approaches to surrogacy, and the welfare of abandoned children, feminists can also promote their own cultural credibility, publicly demonstrating how enhancing women's interests enhances the care of families and children.

\section{Fertility incentives and feminist approaches to family support}

In 2007, after fifteen years of severe demographic panic focused largely on declining fertility, Vladimir Putin established a program designed to stimulate the birthrate. The state maternity capital program provides mothers who give birth to a second or third child a voucher worth about $\$ 10,000$ to help defray the costs of child rearing. Women can use their maternity capital for housing and remodeling costs, the child's education needs, or their own pension savings. Putin justified this state investment-quite substantial in comparison with the previous fifteen years of meager state assistance to families - as compensating for the "dependent and frankly even degraded position within the family" that women suffer when they leave the workforce to take care of children (Putin 2006). Notably, the state has neither facilitated women's ability to achieve a better work-life balance, nor encouraged men to contribute to domestic labor, nor developed highquality childcare services. Instead, it has encouraged women to exit the workforce as a solution to the presumed barriers impeding women from bearing second and third children. Thus, despite Putin's framing of this entitlement as promoting women's needs, maternity capital ties the state's support for families closely to its own pronatalist goals, further entrenching a vision of women as mothers and linking them to the domestic sphere. Moreover, the idea that women can "choose" how to use their maternity capital underscores the state's cynical use of family support, by confronting women with what may be the irreconcilable dilemma of addressing their family's needs (housing), their child's needs (education), or their own needs 
(pension savings). It acknowledges the dire economic situation of many families in Russia while prioritizing the demographic politics of increasing childbearing.

In the section that follows, I examine the ways Russian observers have conceptually coded maternity capital as a gendered concern, albeit not as a matter of women's domination. Recognizing Russian concerns over the gendered politics of maternity capital is necessary for conceptualizing meaningful and viable feminist strategies regarding family support. I then place the topic in dialogue with Funk's concerns around eschewing policies that further entrench women's dependency on the state-concerns echoed by Russian feminist critics of maternity capital. While sympathetic to critiques of the maternity capital program, I caution against the full-scale rejection of state support for child rearing and dependent care, as is implied by some Russian (neo)liberals, feminist or otherwise. I argue instead for a feminist approach to family support that both expects the state to make it economically possible for families to take care of their dependents and recognizes families' rights to privacy in undertaking their caregiving duties in ways that they deem appropriate.

\section{Russian responses to maternity capital}

Prominent responses to maternity capital in Russia follow two logics (Rivkin-Fish 2010). Many commentators, inspired by long-standing socialist ideals that the state should bear some of the burden of raising children, welcome it as a rightful entitlement. They lament that the sum is inadequate to transform people's quality of life, let alone encourage more births. Others criticize the idea of pursuing increases in the birthrate by targeting financial support to women, arguing that men's role in the family needs to be strengthened instead. A typical example of this perspective argues:

In Putin's [statement] he spoke of the experience women have after giving birth of being dependent and degraded in the family. But there's no discussion of the permanent, humiliated position of men, who cannot support their family with dignity on these miserly salaries. . . That is, men must refuse not only to have children, but also to get married and have a family. Maternity capital may worsen this situation: men will become completely unnecessary in the modern world - like, by the way, the family ... it is necessary to consider the role of men, their influence on the demographic crisis. It's completely evident that in order to continue the species, to completely reproduce the nation, a woman needs a 
reliable rear guard: a husband, a provider, and defender from all financial storms and cataclysms. (Ekspert Sibir' 2007)

This argument expresses widespread concerns that a long-standing crisis of masculinity stands at the root of Russia's family crisis, including low fertility (Zdravomyslova and Temkina 2002; Zhurzhenko 2008). It displaces Anglo-American (white) feminist assumptions that men as a class dominate women, highlighting local concerns that many men have suffered systematic humiliation at the hands of both the Soviet state and the contemporary market (Watson 1995; Kay 2006). It proposes that a key aspect of women's interests is the pressing need to reestablish men's connection to the family by affirming their cultural importance as breadwinners and creating the economic conditions whereby men can financially support their families.

\section{Conceptualizing feminist strategies}

Russians' critique of maternity capital as a resource for women taps into a widespread contemporary logic that considers Soviet-era policies of women's equality as having occurred at the expense of men's emasculation and estrangement from families. This logic calls for a renewed patriarchal order and poses serious challenges for feminist strategizing on family support. Although, as noted above, the maternity capital program does not enhance women's economic autonomy while they are raising young children, it does recognize that women are the ones who bear the burden, often including the economic costs of child rearing. A state policy that gave fathers equal access to state financial support for child rearing would likely leave women further abandoned and impoverished. A key feminist challenge, consequently, is finding a strategy that both protects women's right to social support for child rearing and advocates that the state and private businesses facilitate men's participation in family life and child rearing (without restoring a patriarchal domestic order).

In acknowledging that most families confront economic hardship, the maternity capital program also legitimizes the idea that the state should help ameliorate these difficulties - a perspective that acknowledges the severe hardship many women in Russian endure. The dismantling of socialism's welfare entitlements, from free education and health care to full employment, has left women with virtually no social safety net. And while the "free" market has enabled a small minority to become wealthy, employment protections have been severely eroded and many women face blatant discrimination in the labor market. This structured gender inequality high- 
lights the need for feminist political strategies that address the state's obligations toward social welfare, an argument that needs to be carefully combined with liberal concerns regarding the need to promote independent civic action. Indeed, Russian feminists have criticized maternity capital on the liberal grounds that it furthers women's dependency on the state. Feminist scholar Elena Gapova (2006) cautions that this program resembles the Soviet treatment of women-mothers as passive recipients of state assistance; Russian feminists Elena Zdravomyslova and Anna Temkina note how maternity capital subordinates women symbolically and hinders their mobility in the labor force (Rotkirch, Temkina, and Zdravomyslova 2007).

Russian feminist critics thus echo Funk's concerns about the need to promote women's independence from the state, in contrast to American feminists Nancy Fraser and Linda Gordon (1994), who have sought to recast the concept of dependency in US public debate from being considered a sign of failure to being recognized as a central characteristic of human life. Yet while Funk cautions against exporting this "revaluing [of] dependency" to the former socialist context, where citizens' ability to enjoy independent social existence apart from the state has never been widely endorsed or protected, she also-importantly-rejects a neoliberal position denying the legitimacy of state benefits altogether $(2004,717)$. She notes how historical forms of liberalism in the region were social democratic, leaving open the possibility that liberal concerns for autonomy and independence could simultaneously endorse state economic support, what some have called social citizenship.

The debate over family support in Russia reveals that Funk has introduced a series of challenging questions for feminists to further elaborate. It demonstrates the important need to define terms such as "dependence" and "independence" more carefully in devising feminist positions. In a global context where neoliberal politics so often call for the withdrawal of state welfare, feminists must devise strategies for preserving state obligations to assume collective responsibility for social well-being and a commitment to equity. A feminist conceptualization of family support that enables women to gain autonomy in their lives is urgently needed.

One inspiration for such visions emerges from recent feminist work in the United States that sees the active support of the state as necessary for enabling women to achieve individual autonomy. Maxine Eichner (2010) argues for a model of the supportive state that

respects citizens' autonomy by treating them as responsible citizens who are accountable for their choices and relationships with others. The liberal state, in this view, provides a scaffold on which citizens can 
construct their lives, but it does not plan their lives for them, or absolve them of the responsibility to plan carefully and budget wisely to achieve their goals. Yet it maintains that the meeting of dependency needs that these family members perform should be accomplished within institutional structures that facilitate caretaking and human development, and that it is the state's responsibility to secure such institutional structures. This approach recognizes the fact of dependency, and that the ability of families to nurture their members does not simply exist as a matter of fact, or spring up as a matter of spontaneous generation; instead, it is an achievement to be pursued jointly by both citizens and the state. (Eichner 2010, 61)

Eichner's perspective allows us to refute the assumption that any state economic transfers to families represent problematic renewals of Soviet paternalism. The reconciliation she proposes between valuing liberty and care work enables inquiry into how state support might be reconstructed to recognize the value of care work, foster the conditions that enable families to pursue their own goals, and also promote gender equality within and beyond the domestic context. In Russia, this could entail complementing economic support for child rearing or housing allowances for poor families with policies that encourage private businesses to enable the balancing of work and family responsibilities, and that combat the sexualization of women and discrimination against women in the workplace. Given that the vast majority of Russians endorse the notion that the state should assist families in their caretaking work, such positions would hold pragmatic value in legitimizing feminist agendas of gender equality while further promoting the image of feminism as supportive of families.

\section{Conclusion}

Inspired by Funk's cautions about the dangers of mechanistically exporting critiques of American liberalism to Eastern Europe, this article has considered the relevance of key liberal concepts of individual autonomy and a private sphere for feminist interventions in Russian reproductive politics. I argue that defending women's access to abortion can build on local notions that women have a right to individual autonomy, but the neoliberal character of Russia's commercialized surrogacy, by contrast, reveals the limits of individual autonomy and the private sphere for promoting gendered justice. Feminist debates over maternity capital reveal the need for further discussion about how state-sponsored family support might create the conditions for women to realize autonomy and avoid dependency, and the need 
for clarification of what these very concepts could mean in a formerly socialist, now neoliberal context. Funk charted a path toward such hybrid feminist formations when she argued that Anglo-based feminists need to reconsider the value of liberal ideas for this region, even as she recognized that these ideas cannot be imported wholesale: "For feminists to defend some central liberal tenets does not mean an unbridled defense of all aspects of liberalism past and present or of neoliberalism. Such a defense does not exclude support for aspects of socialist thought, including social rights, rights to employment, and abortion rights; nor does it preclude challenges to neoliberal conceptions of the right to property" (Funk 2004, 717).

Indeed, this article has shown how determining the relevance of liberal concepts requires examining the cultural meanings and historical, institutional structuring of specific gendered inequalities to clarify the kinds of concerns at stake for differently positioned Russian women. It also requires understanding the political and organizational contexts of feminist activity in Russia, a topic that I have not had space to address here. In brief, it is notable that Russian feminists and their supporters are just beginning to make public claims on reproductive issues; while many factors shape this situation, it may partly be due to the fact that global configurations of feminist reproductive politics have not been perceived as culturally relevant and politically useful. As recent opposition reveals, Russian liberals are devising locally meaningful strategies for defending abortion access, such as "fight abortion, not women"; Western feminists may find their rhetorics instructive.

Certainly, amid Russia's aggressively nationalist demographic politics, lobbying on behalf of women's interests in reproduction is dangerous. Nationalists have labeled clinics providing abortions as "death factories," leaving them to defend their very existence (Baglikova 2012). I have argued that feminist strategies should aim at legitimizing contraceptive use for ensuring timely, healthy pregnancies and highlighting the dangers that restrictions can bring to women's health and family life. On surrogacy politics, feminists may find themselves curiously sympathetic to the church's condemnation of surrogacy as commodifying and dehumanizing, while further critiquing the gendered discrimination and stigmatization of orphans that motivates infertile women's interest in hiring surrogates. For both surrogacy and family support politics, feminist interventions addressing the inequalities of neoliberalism may be more relevant for addressing women's multiple interests than emphasizing individual autonomy or a private sphere. All three issues reveal the need for strategies that link feminism with both the promotion of women's autonomy and the strengthening of families and other units of caregiving. Hybrid approaches melding liberal and ethicsof-care concerns to establish feminism's relevance for promoting Russian 
women's interests are most essential. Indeed, countering prevalent images of feminism as opposed to families and men, and as threatening national vitality (Antonov and Sorokin 2000), is a most urgent task for feminist engagement in contemporary Russia.

Department of Anthropology

University of North Carolina, Chapel Hill

\section{References}

Antonov, A., and S. A. Sorokin. 2000. Sud'ba Sem'i v Rossii XXI Veka [The fate of the family in Russia in the twenty-first century]. Moscow: Graal'.

Babasyan, Natalia. 1999. "Freedom or 'Life': Secular and Russian Orthodox Organizations Unite in a Struggle against Reproductive Freedom for Women." Current Digest of the Post-Soviet Press 51(12):14.

Baglikova, Irina. 2012. "Kto vinovat v abortakh—vrachi ili vlasti?" [Who is to blame for abortions — doctors or the government?]. Doctor Piter, April 19. http:// doctorpiter.ru/articles/3741/.

Berkhout, Suze G. 2008. "Buns in the Oven: Objectification, Surrogacy, and Women's Autonomy." Social Theory and Practice 34(1):95-117.

Borovoy, Amy, and Kristen Ghodsee. 2012. "Decentering Agency in Feminist Theory: Recuperating the Family as a Social Project." Women's Studies International Forum 35(3):153-65.

Cerwonka, Allaine. 2008. "Traveling Feminist Thought: Difference and Transculturation in Central and Eastern European Feminism." Signs: Journal of Women in Culture and Society 33(4):809-32.

Creuziger, Clementine G. K. 1997. “Russia’s Unwanted Children: A Cultural and Anthropological Study of Marginalized Children in Moscow and St. Petersburg." Childhood 4(3):343-58.

Draganov, V. G. 2011. Proekt, Federal'nyi zakon “O vnesenii izmeneii v Federal'nyi zakon 'Ob osnovnykh garantiiakh prav rebenka v Rossiiskoi Federatsii' i otdel'nye zakonodatel'nye akty Rossiiskoi Federatsii v tseliakh usileniia garantii prava na zhizn" [Bill, Federal Law "On the introduction of changes to the federal law, 'On the basic guarantees of children's rights in the Russian Federation' and separate legislative acts of the Russian Federation with the goal of strengthening the guarantee of right to life"]. Bill no. 556902-5.YaBlor.ru, http://yablor .ru/blogs/tema-dnya-zakonoproekt-556902-5/1689519.

Eichner, Maxine. 2010. The Supportive State: Families, Government, and America's Political Ideals. New York: Oxford University Press.

Ekho Moskvy. 2010. "Pochemu v Rossii abort-eto osnovnoe sredstvo kontratseptsii?" [Why is abortion the main contraceptive method in Russia?]. Radio program, January 20. http://www.echo.msk.ru/programs/figure/650053-echo /\#element-text. 
Ekspert Sibir'. 2007. "Kapital'naia transformatsiia" [A capital transformation]. Demoscope Weekly, January 22. http://demoscope.ru/weekly/2007/0273 /gazeta014.php.

Field, Deborah A. 2007. Private Life and Communist Morality in Khrushchev's Russia. New York: Peter Lang.

Fraser, Nancy, and Linda Gordon. 1994. “ “Dependency” Demystified: Inscriptions of Power in a Keyword of the Welfare State." Social Politics 1(1):4-31.

Funk, Nanette. 2004. "Feminist Critiques of Liberalism: Can They Travel East? Their Relevance in Eastern and Central Europe and the Former Soviet Union." Signs 29(3):695-726.

Funk, Nanette, and Magda Mueller, eds. 1993. Gender Politics and Post-Communism: Reflections from Eastern Europe and the Former Soviet Union. New York: Routledge.

Gal, Susan, and Gail Kligman. 2000. The Politics of Gender after Socialism: A Comparative-Historical Essay. Princeton, NJ: Princeton University Press.

Gapova, Elena 2006. "Vy rozhaite, vy rozhaite, vam zachtetsia" [Give birth, give birth, you will be counted]. Grani.ru, May 25. http://grani.ru/Society/m.106127 .html.

Hemment, Julie 2007. Empowering Women in Russia: Activism, Aid, and NGOs. Bloomington: Indiana University Press.

Holmgren, Beth. 1995. "Bug Inspectors and Beauty Queens: The Problems of Translating Feminism into Russian." In Post-Communism and the Body Politic, ed. E. E. Berry, 15-31. New York: New York University Press.

Johnson, Janet Elise, and Jean C. Robinson, eds. 2007. Living Gender after Communism. Bloomington: Indiana University Press.

Kay, Rebecca. 2006. Men in Contemporary Russia: The Fallen Heroes of Post-Soviet Change? Burlington, VT: Ashgate.

Mikhalych, Sergei, 1997. "Kto i zachem lobbiruet programmy seksual'nogo vospitaniia shkol'nikov" [Who is advocating programs of sexual education and why]. Novaia Gazeta, September 8-14, 10-11.

Novaia Gazeta. 1999. "Planirovanie Nebytiia" [Planning for nonexistence]. August 3-September 5, 13.

Papyrin, Aleksei 2007. "Shtoby abortov stalo men'she" [So that abortions will decrease]. Meditsinskaia gazeta, November 7. http://www.mgzt.ru/article/602/.

Poedinik. 2012. "V. Solov'eva o surrogatnom materinstve: O. Andrei Kuraev VS. L Miliavskaia" [V. Solov'eva on surrogate motherhood]. April 27. Transcript of television program available at http://www.pravmir.ru/poedinok-v-soloveva-o -surrogatnom-materinstve-o-andrej-kurev-vs-1-milyavskaya-videotekst/.

Points, Kari. 2009. "Strategies for Protecting the Health and Human Rights of Surrogates in India: A Multicountry Legislative Analysis.” Master's thesis, Duke University.

Pravitel'stvo RF. [Legislature, Russian Federation]. 2003. "O Perechne Sotsial'nykh Pokazanii dlia iskusstvennogo Preryvaniia Beremennosti" [On the list of social criteria for artificial termination of pregnancy]. Resolution 485. Demoscope 
Weekly, nos. 123-24, August 25-September 7. www.demoscope.ru/weekly /2003/0123/tema03.php.

Putin, Vladimir. 2006. Annual address to the Federal Assembly of the Russian Federation, May 10, Marble Hall, the Kremlin: www.kremlin.ru/eng/speeches /2006/05/10/1823_type70029type82912_105566.shtml.

- 2012. "Postanovlenie Pravitel'stva Rossiiskoi Federatsii ot 6 fevralia 2012 g. No. 98 g.Moskva 'O sotsial'nom pokazanii dlia iskusstvennogo preryvaniia beremennosti' " [The decree of the government of the Russian Federation of February 6, 2012, number 98, in the city of Moscow, "On the social indicators for the artificial termination of pregnancy"]. Federal publication no. 5705. Rossisskaia Gazeta, February 15. http://www.rg.ru/2012/02/15/98-dok.html.

Ragoné, Helena. 1994. Surrogate Motherhood: Conception in the Heart. Boulder, CO: Westview.

Regions.ru. 2011. “U zhenshchin est' pravo reshat' svoiu sud'bu (parlamentarii o probleme abortov)" [Women have the right to decide their own fate (parliamentarians on the problem of abortions)]. April 12. http://www.regions.ru/news $/ 2350149$.

Rivkin-Fish, Michele. 1994. "Communist Transformations and Abortion Politics: Reflections on Feminist Strategies and 'Choice.' " Critical Matrix 8(2):101-26.

- 2005. Women's Health in Post-Soviet Russia: The Politics of Intervention. Bloomington: Indiana University Press.

— 2006. "From 'Demographic Crisis' to 'Dying Nation': The Politics of Language and Reproduction in Russia." In Gender and National Identity in Twentieth-Century Russian Culture, ed. Helena Goscilo and Andrea Lanoux, 151-73. DeKalb: University of Northern Illinois Press.

- 2010. "Pronatalism, Gender Politics, and the Renewal of Family Support in Russia: Toward a Feminist Anthropology of 'Maternity Capital.' 'Slavic Review 69(3):701-24.

Rotkirch, Anna, Anna Temkina, and Elena Zdravomyslova. 2007. "Who Helps the Degraded Housewife? Comments on Vladimir Putin's Demographic Speech.” European Journal of Women's Studies 14(4):349-57.

Roundtable of the Human Rights Seminar. 2011. "Kruglyi stol v ramkakh Seminara po pravam cheloveka, 'Telo Zhenshchiny: pravo vybirat' ili obiazannost' rozhat'?" [Woman's body: The right to choose or an obligation to give birth?]. Livejournal.com, http://pigbig.livejournal.com/659539.html.

Ryan, Maura A. 2009. "The Introduction of Assisted Reproductive Technologies in the 'Developing World': A Test Case for Evolving Methodologies in Feminist Bioethics." Signs 34(4):805-25.

Sakevich, Victoria Ivanovna. 2007. “Abort ili planirovanie sem'i?" [Abortion or family planning?]. Demoscope Weekly, nos. 279-80, March 5-18. http://demoscope .ru/weekly/2007/0279/tema01.php.

. 2012. "Novye ogranicheniia prava na abort v Rossii." [New restrictions on the right to abortion in Russia]. Demoscope Weekly, nos. 499-500, February 20March 4. http://demoscope.ru/weekly/2012/0499/reprod02.php. 
Shanley, Mary Lyndon 2001. Making Babies, Making Families: What Matters Most in an Age of Reproductive Technologies, Surrogacy, Adoption, and Same-Sex and Unwed Parents. Boston: Beacon.

Smirnov, Protoierei Dimitrii. 2011. "Protoierei Dimitrii Smirnov: Surrogatnoe materinstvo srodni prostitutsii” [Archpriest Dimitrii Smirnov: Surrogate motherhood is akin to prostitution]. Pravoslavie i mir, August 29. http://www.pravmir.ru /protoierej-dimitrij-smirnov-surrogatnoe-materinstvo-srodni-prostitucii.

—. 2012. "Pochemu Tserkov' tak aktivno vystupaet protiv surrogatnogo materinstva? O suti iavleniia-spravka PRAVMIRa” [Why does the church so actively stand up against surrogate motherhood? On the core of the phenomenon-an information guide of Pravmir]. Pravoslavie $i$ mir, April 18. http://www.pravmir .ru/surrogatnoe-materianstvo-spravka.

Snitow, Ann. 1999. "Cautionary Tales." American Society of International Law: Proceedings of the Ninety-Third Annual Meeting, 35-42.

Svitnev, Konstantin. n.d. "Russian Legislation.” Report, European Society for Human Reproduction and Embryology. http://www.eshre.com/ESHRE/English /Legal-Matters-and-Guidelines/Legaldocumentation/Russia/Russian-Legislation /page.aspx/184.

Timashova, Natal'ia. 2003. "Mediki vvodiat ogranicheniia na pozdnie aborty v nadezhde povysit' rozhdaemost'" [Doctors introduce restrictions on late term abortions in the hope of raising the fertility rate]. Demoscope Weekly, nos. 123-24, August 25-September 7. www.demoscope.ru/weekly/2003/0123/tema03.php.

Tronto, Joan C. 1993. Moral Boundaries: A Political Argument for an Ethic of Care. New York: Routledge.

Turbine, Vikki. 2007. "Women's Perceptions of Human Rights and Rights-Based Approaches in Everyday Life: A Case Study from Provincial Russia.” PhD dissertation, University of Glasgow.

Watson, Peggy. 1995. "Explaining Rising Mortality among Men in Eastern Europe." Social Science and Medicine 41(7):923-34.

Zabina, Helena, Dmitry Kissin, Elena Pervysheva, Anna Mytil, Olga Dudchenko, Denise Jamieson, and Susan Hillis. 2009. "Abandonment of Infants by HIVpositive Women in Russia and Prevention Measures." Reproductive Health Matters 17(33):162-70.

Zdravomyslova, Elena, and Anna Temkina. 2002. "Krizis Maskulinosti v Pozdnesovetskom Diskurse" [The crisis of masculinity in late Soviet discourse]. In $O$ Muzhe(n)stvennosti [On masculinity], ed. Serguei Oushakine, 432-51. Moscow: Novoe Literaturnoe Obozrenie.

Zhurzhenko, Tatiana. 2008. Gendernye rynki Ukrainy: politicheskaia ekonimiia natsional'nogo stroitel'stva [The gendered markets of Ukraine: The political economy of nation building]. Vilnius: European Humanities University. 